\title{
Feeding the Future with the Past: Incorporating Local Ecological Knowledge in River Restoration
}

\author{
Ewelina Szałkiewicz ${ }^{1}$ (D) Joanna Sucholas ${ }^{2}$ and Mateusz Grygoruk ${ }^{3, *(\mathbb{D}}$ \\ 1 Department of Hydraulic and Sanitary Engineering, Faculty of Environmental Engineering and Spatial \\ Management, Poznań University of Life Sciences, ul. Wojska Polskiego 28, 60-637 Poznań, Poland; \\ sonnenbergewelina@gmail.com \\ 2 Institute of Plant Sciences, Faculty of Biology and Preclinical Medicine, University of Regensburg, \\ Universitätsstr. 31, 93053 Regensburg, Germany; j.sucholas@gmail.com \\ 3 Institute of Environmental Engineering, Department of Hydrology, Meteorology and Water Management, \\ Warsaw University of Life Sciences-SGGW, ul. Nowoursynowska 166, 02-787 Warsaw, Poland \\ * Correspondence: M.Grygoruk@levis.sggw.pl; Tel.: +48-225935309
}

Received: 22 March 2020; Accepted: 20 April 2020; Published: 22 April 2020

\begin{abstract}
Despite many years of experience in the river restoration field, which has become one of the most promising areas of water resources management, significant challenges and problems remain. These include the scope and scale of restoration measures, developing the reference model, assessment of restoration success, and the engagement of local stakeholders. Progress in addressing these challenges to river restoration could be achieved by changes in current approaches through the appreciation and integration of local communities and their local ecological knowledge (LEK). The results of discussion on ecological restoration indicate that ecological knowledge, which combines the interests of local communities and the environment, could be used in restoration projects. However, in the case of river restoration, this type of knowledge is systematically overlooked. In our paper, we discuss common river restoration problems and supportive elements that may be found in LEK. We conclude that the local stakeholders' involvement and strong establishment of their position in the river restoration processes should be reconsidered. We believe that the application of LEK has large potential for improving water resources management and restoration of aquatic ecosystems and remains a key factor in a successful future of river restoration.
\end{abstract}

Keywords: river restoration; local ecological knowledge; traditional ecological knowledge; stakeholders; stakeholders participation; ecological restoration

\section{Introduction}

Since river restoration has become a widely used way of managing water resources and recovering aquatic ecosystems, its results, measures of success, and community engagement have evolved over time. Currently, a wide range of restoration guidelines, principles, brochures, and platforms is available that support river restoration actions [1-5]. However, after dozens of years of restoration experience, the science still emphasizes the challenging nature of restoration endeavors [6]. Many uncertainties can make the recovery of aquatic ecosystems fail $[7,8]$. Moreover, doubts that remain in the basic assumptions of ecosystem restoration make defining the desired state of the restored ecosystem and defining the "success" of a river restoration process a complex task [9]. Some of the problematic matters and challenges in river restoration concern: (1) the scope and scale of restoration measures; (2) developing the reference model; (3) assessment of restoration success; and (4) the engagement of local stakeholders.

A fresh view of river restoration problems may be provided by changes in the current approach. Firstly, analyzing the basics of restoration ecology paradigms may be helpful. We observed that 
some approaches implemented and considered in restoration ecology are less important in river restoration [10-12]. Secondly, taking social aspects more deeply into account may enrich and support river restoration process. Although the stakeholders' involvement is thought to be an important element of any environmental restoration projects, their role is quite often narrowed to the level of "acceptance" of and a passive "support" for the actions planned [13]. We refer to "passive" as support without considering their practices, experience, and knowledge about the ecosystem. For example, local inhabitants used to be involved in workshops or other project-related activities, but had not been present in the process of the project development [13].

Our main idea for solving river restoration issues includes spotting, appreciation, and integration of local communities and their ecological knowledge along with the scientific measures. It has been widely recognized that people who live in a particular place and somehow depend on natural resources develop ecological knowledge which is locally distinctive [14-39]. Thus far, various terms were applied to name such a unique "wisdom": "indigenous knowledge", "traditional and local ecological knowledge", "folk knowledge", etc. Similar to Ellen and Harris [14], we observed that these definitions are often used interchangeably and many overlaps can still be found. Usually, the explanation of elements of this "wisdom" refers to the fact that the knowledge is locally sourced, empirically gained, and developed and transmitted orally through the generations [14]. We used these assumptions to keep the thread of reasoning in this paper.

The paper aims at assembling the river-relevant research describing traditional ecological knowledge (TEK) and local ecological knowledge (LEK). TEK, in the roots of the term, has a wide meaning containing the deep lore, beliefs, and rituals of the indigenous peoples' life [31]. It seems that there is more research providing evidence that TEK, not LEK, is combined with scientific knowledge. Despite many examples of TEK, we intend to indicate LEK, defined as an additional and supportive element in river restoration, to extend possibilities of ecological knowledge use beyond the indigenous people and traditional cultures. Originally, TEK was recognized amid the indigenous societies of the Amazon, British Columbia, and New Guinea [15-20], but in time it was spotted and investigated by scientists among European rural communities as well [21-25]. Interestingly, the earliest ethnoecological studies recognized the complementarity of empirical ecological knowledge to the scientific one [28-30] and proposed general methods of application [33,34]. Case studies of possible implementation of TEK and LEK in conservation biology, sustainable co-management, and ecosystem monitoring are discussed [20,24,26,30,37-39] as well as in the context of restoration ecology [9,27,40,41].

Ecological restoration, and river ecosystem restoration in particular, remains a complex process (Figure 1). However, the use of scientific tools and theoretical models seems to be insufficient in many cases. We claim that restoration projects cannot succeed if the ecological knowledge of local communities, with its own understanding of inhabited ecosystem and place-based experience, is not considered [42]. Nevertheless, the application of LEK in river restoration is systematically overlooked. We claim that a more holistic approach to river restoration is the respect and receptivity for local people's voices, and the incorporation of their experiences. The main aim of the paper is to outline how restoration ecology and appreciation of LEK may support the current river restoration endeavors. We analyze the relevance of LEK at particular stages of river restoration project (Figure 1). For this purpose, we discuss some important problematic matters of river restoration and supportive solutions, which may be found in LEK and restoration ecology. Taking these into account, we argue the following: the basics of restoration ecology should always be principally considered; LEK should be regarded as an important and valid type of knowledge; and local stakeholders' involvement and their position in the river restoration processes should be reconsidered. 


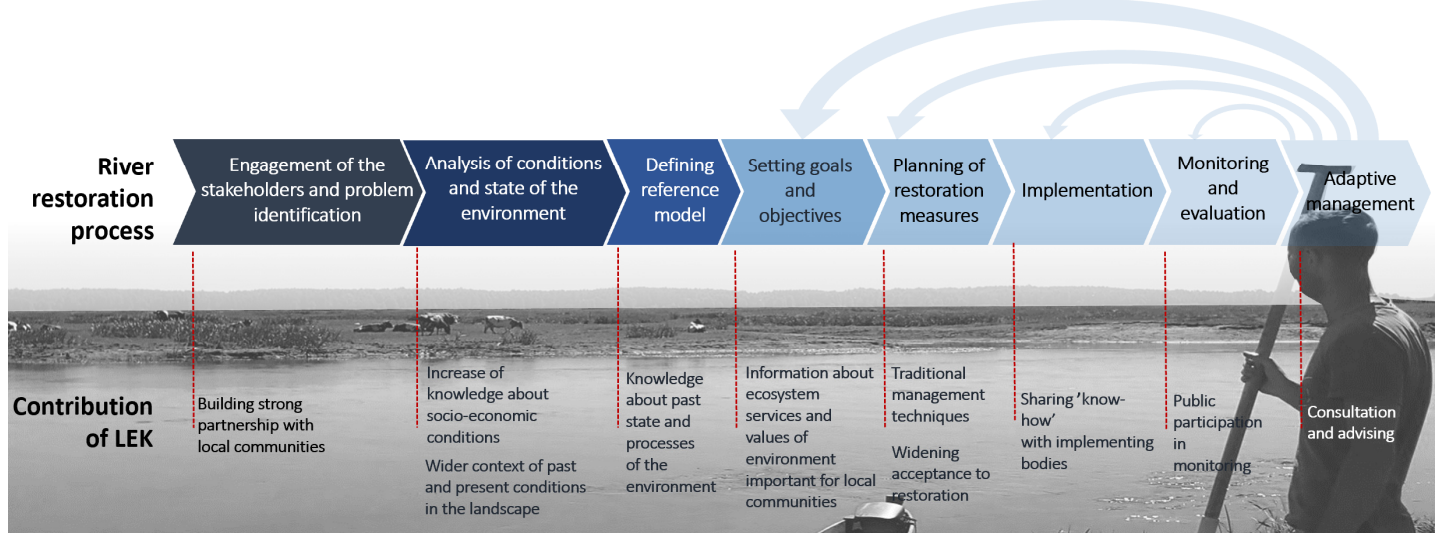

Figure 1. River restoration framework and associated, relevant contribution of LEK at each level of river restoration.

\section{Defining and Explaining LEK}

The unique ecological knowledge is not only limited to indigenous, tribal communities but is also recognized within and between rural societies of Europe [14,21-25] and local people in general, who use natural resources $[35,43]$. When discussing European rural cases, the definition formulated by Molnár et al. [24] should be applied, where instead of TEK more commonly "rural traditional ecological knowledge" is used, being an effect of decades of individual life experiences in a specific landscape. It is developed when people stay in direct contact with nature and manage it by hand. Usually, this knowledge is stored in the centuries-long experiences of the whole local community. In villages, holders of the knowledge are found among farmers, herders, shepherds, and elders [21,23-25,36,44,45]. This definition is most closely related to LEK, knowledge possessed by local but not necessarily indigenous communities. Recently, in the Society for Ecological Restoration (SER) Standard by Gann et al. [10], LEK is defined as "local, place-based knowledge of the land and its processes applied by humans to create more productive lands and healthier ecosystems, increasing biodiversity and improving ecosystem resilience. ( . . . ) Widespread in Europe, for example, LEK includes pre-Industrial Era farming, water management, and subsistence hunting practices. In some places, both LEK and TEK can function together, although they may come from different cultural paradigms". In the existing research in Central Europe, Scandinavia, or US, LEK is recognized among forest users, foresters, fishermen, hunters, landowners [22,35,37,43], and even indigenous people whose traditional practices were discontinued but knowledge remained [37]. This knowledge is not only learned orally from living people but also from historical and ethnographical documents $[35,37,44]$. Ecological knowledge considers local taxonomy of species, landscape perception, ecosystem management, and changes as well as the cognition of ecological processes. Additionally, it incorporates historical data, which the existing generation learned from previous ones or other members of their society. It is worth underlining that sustainability is usually incorporated into the traditional culture and land management $[20,32,35]$ because it ensures the long-term existence of the natural resources on which people depend for their livelihood [33]. Moreover, the discontinuation of traditional practices has been pointed out as a reason for the decline in biodiversity [46,47]. More recently, it has been applied in the context of the restoration projects, collected and comprehensively described by Uprety et al. and Reyes-Garcia et al. [40,48]. Importantly, considering local communities and all types of knowledge when planning restoration projects has also highlighted in paradigms of restoration ecology [11]. Moreover, the traditional cultural ecosystems concept, which was recently included in SER standards, considers ecosystems as the result of co-evolution of plants, animals, and humans in response to past environmental conditions.

The analogies and overlaps between some of the main postulates of restoration ecology and the basic features of local and traditional ecological knowledge seem to be striking. It can be equally interpreted as the relationship where restoration ecology provides its main concerns and questions, 
for which local and traditional ecological knowledge could give the answers because of the main elements incorporated in its nature. Regarding the framework of restoration [49], first, one is advised to aim at the general understanding of how an ecosystem works. Second, one should search for solutions applicable to a specific site and situation. Finally, one should pursue sustainable ecosystem management. This common mechanism makes local ecological knowledge useful for restoration purposes, even for more detailed issues.

In river restoration, the possibility of using knowledge of local communities has started to be appreciated, mainly in the aspect of indigenous people [9,50-52]. The reports about LEK application are still rare. Incorporation of LEK in river restoration and management plans was proposed, e.g., by Mustonen [37], who investigated LEK in the watershed of Jukajoki River, Finland. Through the oral histories and documents, local people told about pre-industrial fisheries, bird habitats, fish ecology and behavior, and causes of degradation. In practice, traditional management is mainly used to restore or keep valuable ecosystems in the floodplains, and local and traditional knowledge about the river per se, is not usually considered or described. For instance, in the Lonjsko Polje Nature Park (Croatia), local communities graze pigs, horses, and cattle at the alluvial lowlands and this management facilitates the appearance of secondary wet grassland and freshwater habitats important for endangered species [53]. The Latvian river restoration initiative, "Place a stone in a Stream", which has been implemented on the Jaunupe River [54], presents an important case where scientists closely cooperated with all possible stakeholders, such as NGOs, land owners, local communities, and authorities, actively engaging them in endeavors of riverine ecosystem improvement. Performed actions were also inspired by and sourced in LEK and former traditional methods of river purifications. This complex approach has thus far led to successful ecological state results and increased their lasting in the future by having an understanding on the sites of people staying in close, everyday relation with the rivers [54].

\section{River Restoration Challenges versus Restoration Ecology and LEK Opportunity}

As mentioned, river restoration is a complex task and many uncertainties can cause the recovery of ecosystems to fail. According to Harris and Heathwaite [8], actions seem to be ineffective because of three reasons: (1) there is low predictability and high uncertainty in the ecological response; (2) monitoring programs are inadequate; and (3) there are difficulties in assessment due to shortcomings at the planning stage. In each group, more specific problematic matters may be identified, e.g., climate change impact, ecosystem's resilience, monitoring timeframe, defining the reference model, measures used for assessment, or application of adaptive management. Nevertheless, in our discussion, we pay attention mainly to issues in which we see evident potential of LEK application and additional reference to restoration ecology. These are: (1) the approaches of river restoration projects; (2) preparing the reference model; (3) assessment of restoration success; and (4) engagement of local stakeholders.

\subsection{Developing River Restoration Approaches}

The scope and scale of river restoration are directly related to the approach that has been adopted. Originally, because of the definition, river restoration was focused on recovering the ecosystem to its pristine state, which could be defined and measured by the presence of specific habitats and organisms and the water quality [12]. The habitat's state approach was based on measures that mainly addressed the riverbed and banks, which caused changes in the channel's form and structure along the river. With time, it has been recognized that the improvement of the static state of the environment was aimed at removing the effects of ecosystem degradation rather than reducing the processes responsible for disturbances [55]. It has also been revealed that the restoration should recover dynamic processes within the ecosystems, being considered in the catchment scale $[3,6,9,12,55-61]$. The latter is based on a wide range of measures, which should recover the ecosystem's connectivity, sediment flux, hydrological processes, and nutrient balance [3]. However, river restoration is also a socioeconomic process, thus more recently, approaches which consider society needs and expectations have been appearing in numbers [62]. One of these was proposed by Dufour and Piégay [58], who noticed that 
the only way to reconcile natural and cultural elements is to move from process-based restoration to objective-based restoration, in which the goals are defined based on "potential functioning" and "societal wishes".

What can be observed is that the scale and scope of river restoration have evolved with time, from habitats and water quality interest to complex ecological and socio-economic concerns. However, because of the complexities of the latter, properly assessed and successful river restoration projects are rare. In the literature, habitat-state-oriented projects are claimed only partly effective, and a process-based approach is recommended [57]. In practice, however, it is difficult to consider them separately, as they both form the scientific background for river restoration actions. Process-based restoration contains measures of habitat-state-oriented restoration, even though their assumptions are different. For instance, dam removal may cause local improvement of hydromorphology and habitats, as well as reinstatement of river and sediment transport continuity. However, it is essential to treat river systems as a whole; habitat-state restoration techniques still take place depending on the scale of the projects (many of which, because of the costs, are divided into smaller parts). Thus, we claim that approaches described by Society for Ecological Restoration (SER) [10] may help to establish proper ecological scope and the scale of river restoration actions. There are three general approaches (Figure 2). The first one is a so-called "natural regeneration", in which damage is low and the environment has the ability to self-heal. When the level of degradation is more profound, "assisted regeneration" is required. In this case, the drivers of ecosystem degradation should be removed, and active interventions should trigger abiotic recovery. In the last approach, "reconstruction", damage to the environment is high. The ecosystem's recovery may be achieved only by the removal and correction of the degradation's causes. Thus, according to the "assisted regeneration" approach, habitat-state measures may be proper to restore some local disturbed reaches, with the assumption that the watershed's integrity is maintained. Approaches proposed by SER do not exclude assumptions of process-based and habitat-state actions; instead, they intuitively help to define restoration goals and measures based on estimation of the scale of damages and potential ecosystem's ability to self-heal. Moreover, in our experience, those approaches are more understandable for practitioners and water management entities.

To include socioeconomic aspects in current river restoration approaches, more engagement of social science is needed [63]. For instance, assessment and definition what is the social success of river restoration in terms of process is required. For practitioners and scientists, those will be improvement of ecosystem services, resilience of the ecosystems, or reinstatement of the processes. For local communities, despite using variety communication strategies, those values and perception of the river restoration (and the area) may be different. In this matter, considering traditional management and local ecological knowledge may be useful. The broad range and holistic attitude of LEK (e.g., traditional management, observations of environment's processes and state, and sustainable use of natural resources) allows considering specific ecological features, as well as social and economic conditions. Thus, incorporating LEK into the restoration may also be connected to landscape restoration approach, in which in-depth understanding of landscape composition, structure, and function, as well as the link between ecological integrity and meeting human needs, is required [64]. Socioeconomic aspects may be extracted based on ecosystem services important for local communities and their traditions. Semi-structured interviews used in ethnoecological studies $[65,66]$ allow recognition of the broader scale and source of the problem, people's expectations, their needs and relations with the landscape and management system. For instance, an 80-year-old male cited by Mustonen [37] told about mires, connection with the Jukajärvi Lake, and causes of degradation: "The mires were far wetter before. It caused the lake great damages when the ditches were made and mires drained to the lake-these waters went straight into the lake. It caused great damages. They used to be cloudberry mires, and we of course went there constantly." Another story provided knowledge about fishing, which has been and still is an important subsistence and cultural activity in the watershed [37]. Furthermore, dialog between local communities, practitioners, and scientists may help in conducting 
adaptive management, which was indicated in studies carried in collaboration with members of three indigenous communities (in the United States, New Zealand, and Canada) who were engaged in river restoration [27]. What is important is that incorporating LEK and considering related socioeconomic aspects do not exclude assumptions of more specific ecological approaches (those in river restoration, as well as in restoration ecology); instead, they may provide complementary types of knowledge and restoration techniques matched to specific areas [10].
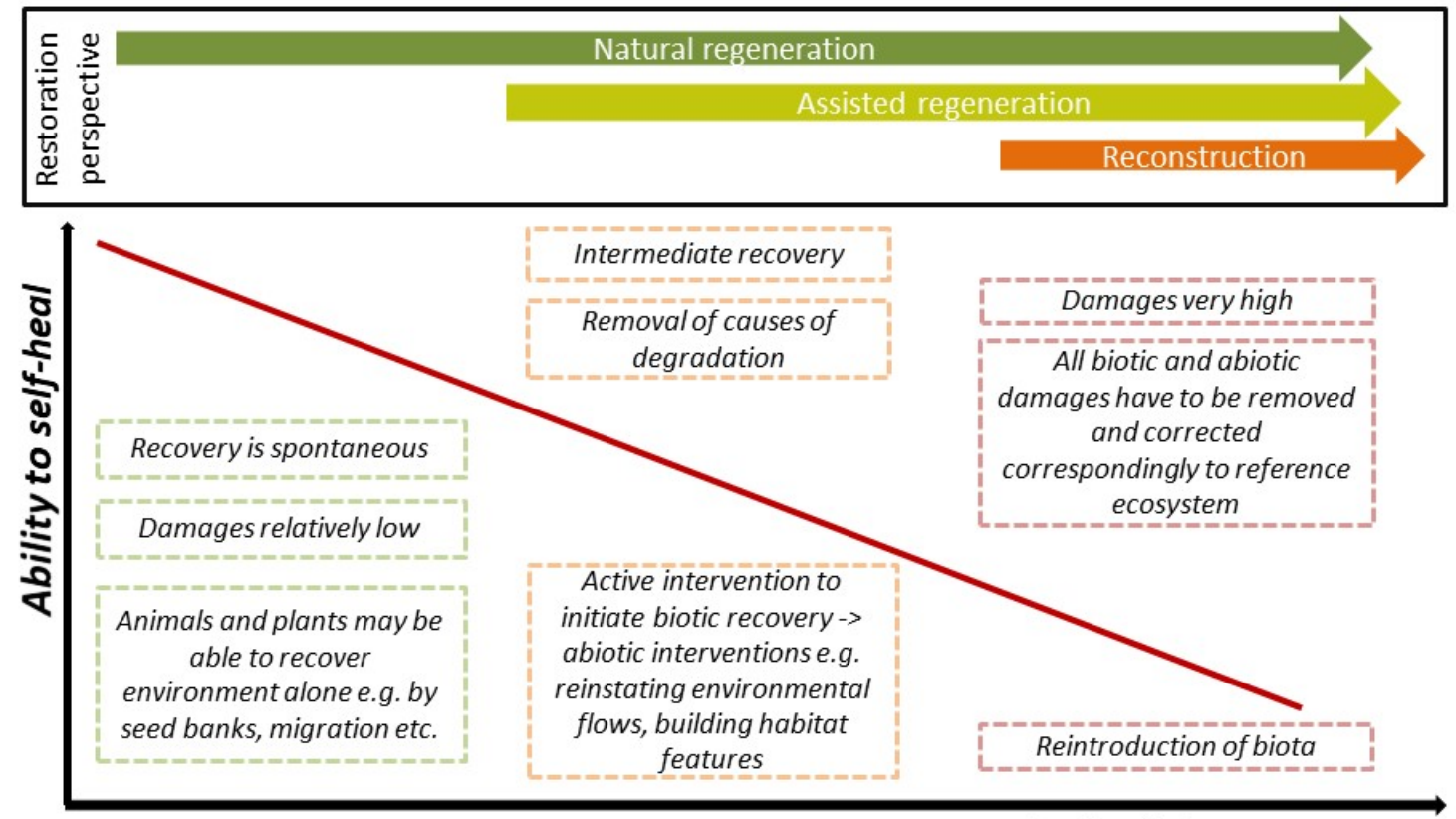

Scale of damages

Figure 2. Graphical interpretation of approaches used in ecological restoration (based on Gann et al. [10] and Biedroń et al. [67], modified).

Unfortunately, together with developing new approaches, the problematic matters are the time lags between their descriptions and practical application [68]. Although scientists discussed processed-based restoration more than a dozen years ago, outputs obtained with these measures are still rare [69]. The number of restoration projects, which have been addressed on a scale reaching beyond the river channel, have been increasing in the last decades; however, most of them are still directed at the channel itself $[57,70]$. This may also be due to the above-described scale of the projects and division into smaller implementation parts. Nevertheless, Naiman [62] stated that projects that are addressed to the proper spatial scale of the problem and the key socioecological drivers of degraded conditions are still singular.

The concept of considering LEK in the river restoration may meet the same time lags. However, local people are experienced in their techniques, which may alleviate this delay. For instance, methods recommended in Latvia to decrease macrophytes overgrow contain old local techniques such as mowing with a scythe or devices mounted on a tractor or boat, but still are recognized as applicable and effective [54]. River restoration is still a developing field; thus, some solutions have not been tested over enough time in contrast to TEK and LEK, which are the results of long-term experimentation and observation $[24,40]$. Additionally, TEK and LEK are changeable and adaptable to unpredictable environmental dynamics [71]. The study performed by Gómez-Baggethun et al. [72] in southern Spain indicates that utilizing TEK can increase socioecological resilience for even serious disturbances in ecosystems caused by climate change. 


\subsection{Developing the Reference Model in River Restoration}

Measures of efficiency in restoration should not be based on the fact that the restoration "was completed" because the planned actions were fulfilled. When planning river restoration actions, it is therefore vital to set the goals one wishes to achieve. It has been thought that these goals should be based on an appropriate reference (response) model, which should be subsequently used as a guideline with which to assess restoration success $[49,60,61,73,74]$. The model provides information about what system behavior (processes) and structure might be expected at the analyzed site [60]. In other words, the response model should recognize the spatial and temporal variability of river ecosystems (its diversity and dynamics). Conceptualization of spatial and temporal variability [12]: (1) excludes restoration to static equilibrium state; (2) assumes that historical data help to indicate how a system functioned in the past, instead of determine the historical state to which restoration should proceed; and (3) facilitates acceptance that the dynamics and diversity of rivers are important for sustainable river restoration. Thus, relying on spatial and temporal variability is also related to process-based approach of river restoration.

Information regarding "what the river should be like" may be provided by various types of data: historical evidence and knowledge, reference site, hydraulic modeling, general stream classifications, and common sense $[6,49,58,61]$. However, the data may be incomplete or the apparent structure and composition may mask the invisible differences in functions $[49,75]$. Moreover, the overall perception of restoration goals and interpretation of data is a subjective matter. Thus, some information may be misinterpreted, and many uncertainties alter the restoration outputs [8]. What is important is that in many cases the response model does not consider socioeconomic aspects $[9,49,60]$.

In recent the SER Standards [10], the reference model is informed not only by reference site or historical data and evidences, but by native ecosystems including traditional cultural ecosystems as well. Moreover, the importance of various types of knowledge is highlighted $[10,49,76]$. This may include TEK/LEK, the practitioners' experience, and the researchers' support, including experts with multiple years of experience. In river restoration, mainly historical knowledge is appreciated, as it can indicate how a system functioned in the past and may provide some trajectories of future changes $[6,49,61]$, but traditional cultural ecosystems and LEK are usually missed, although those may enrich the process of defining the response model and fulfill knowledge gaps about the area (including socioeconomic drivers of biodiversity).

People who possess LEK are good at observing the environment, especially extreme events, variations, and unusual patterns [37,38]. Therefore, one of the biggest contributions of LEK to restoration concerns is a knowledge about past and present conditions, which may indicate: (1) species' composition, distribution, and behavior; (2) management techniques; or (3) the spatial and temporal scale of changes and disturbances $[37,40,77]$. In other words, people are able to tell (for example, by using typonyms) how different sides are used; which values present for the community; which resources are available; what plants and animals they observe; what is in abundance and the distribution of the species; how seasonality, temperature, and weather alter the environment; what disturbances they observe; or what the spatial scale of changes is [27,37]. All this information may be used when preparing a response model $[48,77]$. Moreover, the provided information indicates static (e.g., habitat composition and species' abundance) and dynamic conditions (e.g., direction of changes, rate of changes, and response of the environment), which is difficult to achieve based only on historical evidence or reference sites [49]. LEK could also allow the verification of information gathered by scientists, which increases data validity [40]. For instance, Mustonen [37] quoted another narrative: "then it is a time when the bays are sloshing when big bream fish come to spawn, they are midsummer bream, it comes around both sides of midsummer. The water temperature affects it and also air needs to be still and hot, over $25^{\circ} \mathrm{C}$. When the air is still you can see their fins. There is not a lot of bream and when nets become dirty so easily we do not fish them so much." 


\subsection{Monitoring and Assessment of River Restoration Success}

The criteria of Palmer et al. [61] for ecologically successful river restoration became a paradigm for properly planned and implemented river restoration projects. Nevertheless, Wohl et al. [12] argued that the majority of projects do not satisfy those central requirements. The failures of the actions and problems with assessment may be due to time lags. These consist of delays associated with the time needed to install or adopt measures leading to the improvement, the time required to manifest the measures in a body of water, and the time needed to achieve a response in a body of water [68]. Time lags indicate that the proper time frame of an assessment is required, and it is strictly related to monitoring river restoration projects, which should last long enough to observe the full spectrum of positive and negative restoration effects. Unfortunately, quite often, insufficient (or short) pre- and post-restoration monitoring makes such an assessment impossible [12,70,75]. Even if the monitoring framework is appropriate, due to the lack of monitoring at the control site, one might not be sure that changes are caused by restoration actions or are being driven by some external, broad-scale processes, such as climate changes $[7,78]$.

Monitoring of restoration results should be compared with the assumed model of ecological response. Again, however, studies indicate that less than a half of terrestrial ecosystem restoration projects used a reference model to compare their results to [79], which may indicate that the problem may also occur in river restoration projects. Furthermore, there is confusion in terms of what improvement is good enough to call a restoration successful, in terms of ecological as well as social conditions $[9,79,80]$, and perception of success may be subjective [81].

It is difficult to define a clear approach toward the assessment of river restoration actions (that would consider environmental and socioeconomic aspects), as each site is specific. Hence, more general guidelines appear, e.g., PRAGMO [82] or those in SER Standards [10]. Nevertheless, to solve current problems with monitoring and assessment, a systematic and conscientious approach towards definition of response model, specific goals/objectives, and monitoring frame (in scale of each project) are needed, as restorations succeed when the assumed goals have been met [11]. The support in this matter, especially to assess and achieve social success, may be participatory monitoring and considering the interests of the local communities in assumed goals $[10,11]$. Participatory monitoring engages local stakeholders in the process of collection and analysis of data resulting from restoration [10]. Such partnerships can improve collaboration between stakeholders, make more satisfying decisions, and strengthen stakeholder capacity and empowerment. Importantly, such monitoring is more beneficial when it relies on information sources and methods that are relevant to stakeholders, rather than conventional scientific approaches [10]. An additional contribution can be found in LEK, which also fits very well to the concept of participatory monitoring. Observation of nature is common among traditional users [26,38]. Monitoring based on LEK may be long term, rapid, and low cost, which are very often the limiting factors of current monitoring frameworks [12,38]. The proximity of users also allows day-to-day change observations [26], and the monitoring can be more beneficial and efficient as it is performed by people with the best local knowledge about ecosystem, its spatial recognition, and their own critical way of observation and events notification. An interesting example was provided by Ballard et al. [43], where long-term, community-based forest management projects were studied. In seven various demonstration initiatives, local communities were involved in the ecological stewardship of forest ecosystem. First, they were recognized as valuable participants which can fill the gaps of scientific methods. Second, the projects aimed to improve economic and social state of local community along with a good health of forest ecosystem. Local rangers, forest workers, and residents actively participated in design of management and monitoring together with hired scientists. Moreover, local people were engaged in practical monitoring, data collection, and results interpretation, frequently by using scientific methods on which they were trained. LEK of collectors of forest products and private forest owners was documented and applied in activities design. The projects distinguish themselves by the complex and equal to scientific involvement of LEK and local people in management and monitoring of ecosystem. Specific use of LEK was also implemented in a number of North Iberian rivers 
in an AMBER project (Adaptive Management of Migration Barriers in European Rivers) [83], where local people were involved in studies on alien species. The analyzed projects present multidimensional involvement of local people and LEK in an ecological management; nevertheless, the authors concluded the engagement as still not significant enough and not equal to the scientific part. The adduced projects demonstrate practical possibility and benefits of local people engagement in monitoring process. It supports an argument that other ecological project, such as river restoration, could also research this method by designing its own way of collaboration with local community.

\subsection{The Involvement of Local Stakeholders in River Restoration}

Societal expectations, awareness, acceptance, and engagement are crucial and, in many cases, are thought of as a key to "successful" restoration $[3,9,60,84]$. Thus far, engaging local communities in the endeavor to increase the sense of ownership and the benefits provided by healthy ecosystem has been advised [3,6,13,60,61]. As stated by McDonald et al. [60], restoration goals are strongly influenced by public opinion and are open to dispute through the decision-making process. Thus, for a long time, the actions undertaking the involvement of local communities were driven to alleviate conflicts of interest, which would threaten the projects oriented toward restoring ecological values. Afterward, the importance of social needs has increased, as restoration is an ecological as well as a social process, as mentioned above. Nevertheless, the human dimension in river restoration has thus far been inadequately defined because it is usually narrowed to socioeconomic concerns, such as recreation, flood protection, ecosystem services, or management processes [27]. For example, Webber [85] noticed that "not only 'experts' have information useful to reaching restoration goals". Local stakeholders thus far have not been appreciated and considered to be knowledgeable by scientists. Such an approach by river management practitioners has made people unaware of their potential and the value of the knowledge they possess for years. This is evidenced by lack of involvement in defining the reference model or the scope of the projects. As a result, there is still evident distance between science and local communities, which should not be the case in any adaptive management field [13], especially in a practical field such as river restoration.

In restoration ecology, socio-oriented approaches appeared much earlier $[42,49,76,86]$, and now they consider cultural needs as well $[10,11]$. Thus, in the restoration process, all types of stakeholders should be engaged and special attention should be paid to local communities, their needs, experience, and knowledge. For this reason, we claim that the position of local communities in the current process should be reconsidered. Reyes-Garcia et al. [48] identified that local communities participate in restoration process activities in three ways: (1) by maintaining traditional practices; (2) by restoring land degraded by other people; and (3) by joining restoration groups. Traditional practices combine the use of natural resources (desirable from an economic point of view) with their protection, by maintaining high quality ecosystems to keep the durability of resources [26]. Furthermore, it may increase biodiversity $[24,26,36,87,88]$. When considering LEK, information about species and places important to the community can be extracted [89]. This knowledge indicates ecosystem services provided by local ecosystems [48] and may be used when planning key measures and adaptive management [13].

Apart from more pragmatic benefits, the application of LEK may support and build a fair relationship between scientists and local stakeholders, which currently seems to be difficult to be achieved in river restoration. A common attitude the scientists have toward local practitioners was aptly described by Johannes [90]: "Imagine people who confidently assume they can best describe and manage the natural resources of an unfamiliar region alone ignoring local hunters who know every cave and waterhole and the movements and behavior of a host of local species. Such, historically, has been the custom of most scientists and natural resource managers working in unfamiliar environments". An example of fair relationship between scientists, local communities, management authorities and indigenous people was described in the study of Fox et al. [27], where indigenous people involved in river restoration had "gone from being researched to doing research". They also shared stories and 
perspectives with the wider, non-tribal community what caused increase of trust and understanding. The same process may occur when implementing local ecological knowledge in river restoration. First, involving LEK shows an appreciation of the local people as specialists. Second, implementing traditional practices may increase the community's trust of implemented actions. Finally, understanding local conditions may ensure the community that scientists seek to achieve the well-being of local resources. Even if people are engaged in the river restoration process, without the confidence of the appropriateness of the activities undertaken, they will discontinue restoration actions in the long term.

LEK has the potential in the river restoration field $[9,10,27]$, but not every aspect of it may be used in the applied ecology (Figure 1). Uprety et al. [40] argued that due to changes in conditions, loss of the meaning, or the stagnation and irrelevance over time, the application of some traditional practices may be useless. Another problem may be the application of LEK in current management schemes, which may neither support nor suit the local context $[9,24,39,41]$. For instance, in an already implemented forest management project integrating local communities and their knowledge, economic, political, and legislative obstacles preventing LEK to flourish were recognized [35,43]. Nevertheless, when considered with caution, LEK can help to fill the gaps in the stakeholders' understanding of ecological processes [40] and provide a balance between ecosystem recovery and societal needs. As stated by Collier [9], "involving cultural values can rebalance the conversation from a focus on human needs more towards sustaining certain ecological functions through grounding in traditional practice and knowledge". The contribution of LEK provides something more than the approaches used in river restoration because people's awareness of the world and their experiences are appreciated. This allows them to understand the restoration actions and provide help to maintain traditional practices, which is beneficial for the community and helps repair human-river relationships [27].

Finally, we state that the applicability of LEK in river restoration can improve adaptive management of ecosystems, by providing a valuable feedback to setting and verifying goals of river restoration, adjustment of restoration measures when they have been proved as ineffective, and monitoring and implementation (Figure 1). Then, eventually, even in cases of not completely effective river restoration projects, the active involvement of local people and appreciation of their site-related knowledge may allow this method of river management to be recognized as a tool applied on their demand rather than a kind of intrusive action of managers from beyond. One can better accommodate his/her own ideas than those of others.

\section{Conclusions and Recommendations}

Water resources management through river restoration requires a comprehensive approach that addresses issues of a physical, ecological, socioeconomic, and cultural nature $[9,58,60]$. As a result, contemporary river management is still far from satisfactory, especially in regard to river restoration success [61]. By highlighting the main issues, threats, and opportunities, we intend to indicate the need to improve these approaches and propose supportive solutions rather than criticize the current practices. First, we propose that river restoration plans and projects should draw from restoration ecology. In both fields, approaches evolved with the time; however, current approaches in restoration ecology define basic issues (such as involvement of local communities) more properly than in the field of river restoration. Second, similar to Fox et al. [27] and Collier et al. [9], we maintain the importance of LEK and TEK in river restoration. Thus, local stakeholders' involvement and their position in current processes and projects should be reconsidered. We claim that the knowledge about the extensive use of rivers and riverine landscapes would provide a balance between ecosystem recovery and a local society's needs (Figure 1). Additionally, the appreciation of people's knowledge about habitats, organisms, ecological processes, and landscapes and their ability of observation can contribute to alleviating the presented river restoration problems. The utility of LEK has already been recognized in restoration ecology $[10,41,42,49]$. In river restoration, this approach is relatively new $[27,37,50,51]$, and, in most cases, LEK is still systematically overlooked (e.g., when preparing a response model). Scientists, in most cases, are unaware of or reluctant to use local ecological knowledge as a valid type 
of knowledge. We claim that it may be due to different interpretations and understanding of what it means for something to be "tested". For scientists, such experiments will be designed well and will have enough replicates, while, for local people, day-by-day observation and the empirical knowledge gathered by ancestors will suffice. Additionally, such a way of thinking is a challenge for scientists, who are used to assessing ecosystems via quantity-based data [9]. Another reason for this may be the negative attitudes scientists have toward local people as perpetrators of degradation.

Incorporating LEK into river restoration faces several challenges, from gathering and understanding data to its incorporation in the management process [39,40,48]. Contribution of LEK to restoration activities is still absent in the decision-making process, even though it provides promise for improving management [9,24,41]. Moreover, even if it appears in restoration guidelines [10,11], practical hints for how to gather, use, and implement LEK in river restoration are still required. This would allow finding overlapping aspects of river restoration by increasing social acceptance and allowing the managed river environment to face future challenges with higher level of resilience, resulting in freshwater biodiversity persisting under changing scenarios and novel pressures.

Author Contributions: E.S. and M.G. developed concept of a paper. E.S. and J.S. wrote first draft of the manuscript. M.G. corrected the first draft of the manuscript and prepared final draft for the submission. All authors have read and agreed to the published version of the manuscript.

Funding: This research received no external funding.

Acknowledgments: The authors wish to acknowledge anonymous reviewers of former drafts of this manuscript that allowed us to improve the clarity of the main messages of the paper.

Conflicts of Interest: The authors declare no conflict of interest.

\section{References}

1. Fisher, K.; Holloway, J.; Mant, J.; Holmes, N. River Restoration Strategy and Plan. River Nar Site of Special Scientific Interest. Environmental Agency \& Natural England. 2010. Available online: http://www.therrc.co. uk/DesignatedRivers/Nar_Restoration_Plan_FINAL_APPROVED.pdf (accessed on 25 July 2018).

2. Fokkens, B. (Ed.) Rivers by Design. Rethinking Development and River Restoration. A guide for Planners, Developers, Architects and Landscape Architects on Maximizing the Benefits of River Restoration; Environment Agency, Horizon House: Bristol, UK, 2013.

3. Roni, B.; Beechie, T. (Eds.) Stream and Watershed Restoration, A Guide to Restoring Riverine Processes and Habitats; Willey-Blackwell: Hoboken, NJ, USA, 2012.

4. $\quad$ Speed, R.; Li, Y.; Tickner, D.; Huang, H.; Naiman, R.; Cao, J.; Lei, G.; Yu, L.; Sayers, P.; Zhao, Z.; et al. River Restoration: A Strategic Approach to Planning and Management; UNESCO: Paris, France, 2016.

5. Woosley, S.; Capelli, F.; Gonser, T.; Hoehn, E.; Hostmann, M.; Junker, B.; Paetzold, A.; Roulier, C.; Schweizer, S.; Tiegs, S.D.; et al. A strategy to assess river restoration success. Freshw. Biol. 2007, 52, 752-769.

6. Suding, K.; Higgs, E.; Palmer, M.; Callicot, J.B.; Anderson, C.B.; Baker, M.; Gutrich, J.J.; Hondula, K.L.; LeFavor, M.C.; Larson, B.M.H.; et al. Committing to ecological restoration. Science 2015, 348, 638-640. [CrossRef] [PubMed]

7. Dorau, K.; Gelhausen, H.; Esplör, D.; Mansfeldt, T. Wetland restoration management under the aspect of climate change at a mesotrophic fen in Northern Germany. Ecol. Engin. 2015, 84, 84-91. [CrossRef]

8. Harris, G.P.; Heathwaite, A.L. Why is achieving good ecological outcomes in rivers so difficult. Freshw. Biol. 2012, 57, 91-107. [CrossRef]

9. Collier, K.J. Editorial: Measuring river restoration success: Are we missing the boat? Aquat. Conserv.: Mar. Freshw. Ecosyst. 2017, 27, 572-577. [CrossRef]

10. Gann, G.D.; McDonald, T.; Walder, B.; Aronson, J.; Nelson, C.R.; Jonson, J.; Hallett, J.G.; Eisenberg, C.; Guariguata, M.R.; Liu, J.; et al. International principles and standards for the practice of ecological restoration. Second edition. Restor. Ecol. 2019, 27, S1-S46. [CrossRef]

11. Keenleyside, K.A.; Dudley, N.; Cairns, S.; Hall, C.M.; Stolton, S. Ecological Restoration for Protected Areas: Principles, Guidelines and Best Practices; IUCN: Gland, Switzerland, 2012.

12. Wohl, E.; Lane, S.N.; Wilcox, A.C. The science and practice of river restoration. Water Resour. Res. 2015, 51, 5974-5997. [CrossRef] 
13. Grygoruk, M.; Rannow, S. Mind the Gap! Lessons from science-based stakeholder dialogue in climate-adapted management of wetlands. J. Environ. Manag. 2017, 186, 108-119. [CrossRef]

14. Ellen, R.; Harris, H. Introduction. In Indigenous Environmental Knowledge and its Transformations. Critical Anthropological Perspectives; Ellen, R., Parkes, P., Bicker, A., Eds.; Harwood Academic Publishers: Amsterdam, The Netherlands, 2000; pp. 1-33.

15. Hunn, E.S. N'ch'i-Wana, "The Big River": Mid-Columbia Indians and their Land. Seattle; University of Washington Press: Washington, DC, USA, 1990.

16. Nazarea, V.D. (Ed.) Ethnoecology: Situated Knowledge/Local Lives; University of Arizona Press: Tucson, AZ, USA, 1999.

17. Posey, D.A. Indigenous ecological knowledge and the development of the Amazon. In The Dilemma of Amazonian Development; Moran, E.F., Ed.; Westview Press: Boulder, CO, USA, 1983; pp. 225-257.

18. Rappaport, R.A. Pigs for the Ancestors, Ritual in the Ecology of a New Guinea People; Yale University Press: New Haven, CT, USA; London, UK, 1967.

19. Toledo, V.M. What is Ethnoecology? Origins, Scope and implications of a Rising Discipline. Ethnoecologica 1992, 1, 5-21.

20. Turner, N.; Boelscher, I.; Ignace, R. Traditional Ecological Knowledge and Wisdom of Aboriginal Peoples in British Columbia. Ecol. Appl. 2000, 10, 1275-1287. [CrossRef]

21. Babai, D.; Molnár, Z. Small-scale traditional management of highly species-rich grasslands in the Carpathians. Agriculture. Ecosyst. Environ. 2014, 182, 123-130. [CrossRef]

22. Demeter, L. Biodiversity and ecosystem services of hardwood floodplain forests: Past, present and future from the perspective of local communities in West Ukraine. In Knowing our Land and Resources: Indigenous and Local Knowledge of Biodiversity and Ecosystem Services in Europe E Central Asia, Knowledges of Nature 9; Roué, M., Molnár, Z., Eds.; UNESCO: Paris, France, 2016; pp. 6-19.

23. Meilleur, B. Alluetain Ethnoecology and Traditonal Economy: The Procurement and Production of Plant Resources in the Norhern French Alps. Ph.D. Thesis, University of Washington, Washington, DC, USA, 1986.

24. Molnár, Z.; Bartha, S.; Babai, D. Traditional ecological knowledge as a concept and data source for historical ecology, vegetation science and conservation biology: A Hungarian perspective. In Human Nature. Studies in Historical Ecology and Environmental History; Szabó, P., Hedl, R., Eds.; Institute of Botany of the ASCR: Brno, Czech Republic, 2008; pp. 14-27.

25. Sucholas, J.; Molnár, Z.; Poschlod, P.; Luick, R. Traditional knowledge and management in the shadow of modern conservation-The case of wet grasslands in Biebrza National Park, Poland. Presented at the 16th Congress of the International Society of Ethnobiology, Belem, Brasil, 7-10 August 2018.

26. Berkes, F.; Colding, J.; Folke, C. Rediscovery of traditional ecological knowledge as adaptive management. Ecol. Appl. 2000, 10, 1251-1262. [CrossRef]

27. Fox, C.A.; Reo, N.J.; Turner, D.A.; Cook, J.; Dituri, F.; Fessell, B.; Jenkins, J.; Johnson, A.; Rakena, T.M.; Riley, C.; et al. "The river is us; the river is in our veins": Re-defining river restoration in three Indigenous communities. Sustain. Sc. 2017, 12, 521-533. [CrossRef]

28. Hunn, E.S. What is traditional ecological knowledge? In Traditional Ecological Knowledge: Wisdom for Sustainable Development; Williams, N.M., Baines, G., Eds.; Centre for Resource and Environmental Studies, Australian National Univeristy: Canbera, Australia, 1993; pp. 13-15.

29. Posey, D.A. Topics and issues in ethnoentomology, with some suggestions for the development of hypothesis generation and testing in ethnobiology. J. Ethnobiol. 1986, 6, 99-120.

30. Schultes, R.E. Primitive plant lore and modern conservation. Orion 1998, 7, 8-15.

31. Berkes, F. Sacred Ecology. Traditional Ecological Knowledge and Resource Management; Taylor and Francis: Philadelphia, PA, USA; London, UK, 1999.

32. Posey, D.A.; Dutfield, G. Indigenous Peoples and Sustainability: Cases and Actions; International Union for the Conservation of Nature and International Books: Utrecht, The Netherlands, 1997.

33. Huntington, H.P. Using Traditional Ecological Knowledge in Science: Methods and Applications. Ecol. Appl. 2000, 10, 1270-1274. [CrossRef]

34. Berkes, F.; Turner, N.J. Knowledge, Learning and the Evolution of Conservation Practice for Social-Ecological System Resilience. Hum. Ecol. 2006, 34, 479-494. [CrossRef]

35. Charnley, S.; Fischer, A.P.; Jones, E.T. Integrating traditional and local ecological knowledge into forest biodiversity conservation in the Pacific Northwest. For. Ecol. Manag. 2007, 246, 14-28. [CrossRef] 
36. Babai, D.; Tóth, A.; Szentirmai, I.; Biró, M.; Máté, A.; Demeter, L.; Szépligeti, M.; Varga, A.; Molnár, A.; Kun, R.; et al. Do conservation and agri-environmental regulations effectively support traditional small-scale farming in East-Central European cultural landscapes? Biodivers. Conserv. 2015, 24, 3305-3327. [CrossRef]

37. Mustonen, T. Oral histories as a baseline of landscape restoration-Co-management and watershed knowledge in Jukajoki River. Fennia 2013, 191, 76-91. [CrossRef]

38. Moller, H.; Berkes, F.; Lyver, B.O.; Kislalioglu, M. Combining science and traditional ecological knowledge: Monitoring populations for co-management. Ecol. Soc. 2004, 9, 2. [CrossRef]

39. Houde, N. The six faces of traditional ecological knowledge: Challenges and opportunities for Canadian co-management arrangements. Ecol. Soc. 2007, 12, 34. [CrossRef]

40. Uprety, Y.; Asselin, H.; Bergeron, Y.U.; Doyon, F.; Boucher, J.F. Contribution of traditional knowledge to ecological restoration: Practices and applications. Ecoscience 2012, 19, 225-237. [CrossRef]

41. Wehi, P.M.; Lord, J.M. Importance of including cultural practices in ecological restoration. Conserv. Biol. 2017, 31, 1109-1118. [CrossRef] [PubMed]

42. Higgs, E.S. What is good ecological restoration? Conserv. Biol. 1997, 11, 338-348. [CrossRef]

43. Ballard, H.L.; Fernandez-Gimenez, M.E.; Sturtevant, V.E. Integration of Local Ecological Knowledge and Conventional Science: A Study of Seven Community-Based Forestry Organizations in the USA. Ecol. Soc. 2008, 13. [CrossRef]

44. Varga, A.; Molnár, Z.; Biró, M.; Demeter, L.; Gellény, K.; Miókovics, E.; Molnár, Á.; Molnár, K.; Ujházy, N.; Ulicsni, V.; et al. Changing year-round habitat use of extensively grazing cattle, sheep and pigs in East-Central Europe between 1940 and 2014: Consequences for conservation and policy. Agric. Ecosyst. Environ. 2016, 234, 142-153. [CrossRef]

45. Netting, R.M. Balancing on an Alp. Ecological Change and Community in a Swiss Mountain Community; Cambridge University Press: Cambridge, UK, 1981.

46. Palang, H.; Printsmann, A.; Konkoly-Gyuro, E.; Urbanc, M.; Skowronek, E.; Woloszyn, W. The forgotten rural landscapes of Central and Eastern Europe. Landsc. Ecol. 2006, 21, 347-357. [CrossRef]

47. Schmitt, T.; Rakosy, L. Changes of traditional agrarian landscapes and their conservation implications: A case study of butterflies in Romania. Divers. Distrib. 2007, 13, 855-862. [CrossRef]

48. Reyes-García, V.; Fernández-Llamazares, A.; McElwee, P.; Molnár, Z.; Öllerer, K.; Wilson, S.J.; Brondizio, E. The contributions of Indigenous Peoples and Local Communities to ecological restoration. Restor. Ecol. 2018. [CrossRef]

49. Hobbs, R.J.; Harris, J.A. Restoration ecology: Repairing the earth's ecosystems in the new millennium. Restor. Ecol. 2001, 9, 239-246. [CrossRef]

50. Aigo, J.; Ladio, A. Traditional Mapuche ecological knowledge in Patagonia, Argentina: Fishes and other living beings inhabiting continental waters, as a reflection of processes of change. J. Ethnobiol. Ethnomed. 2016, 12, 56. [CrossRef] [PubMed]

51. Mesquita, E.M.C.; Isaac-Nahum, V.J. Traditional knowledge and artisanal fishing technology on the Xingu River in Pará, Brazil. Braz. J. Biol. 2015, 75, 138-157. [CrossRef] [PubMed]

52. Raymond-Yakoubian, J.; Raymond-Yakoubian, B.; Moncrieff, C. The incorporation of traditional knowledge into Alaska federal fisheries management. Mar. Policy 2017, 78, 132-142. [CrossRef]

53. Gugič, G. Managing Sustainability in Conditions of Change and Unpredictability: The Living Landscape and Floodplain Ecosystem of the Central Sava River Basin; Lonjsko Polje Nature Park Public Service: Krapje, Croatia, 2009.

54. Urtāns, A.V.; Urtāns, L. Water Courses of Plain to Montane Levels with Ranunculion Fluitantis and Callitricho-Batrachion Vegetation. In The Protected Habitat Conservation Guidelines in Latvia, Volume 2 Rivers and Lakes; Urtāns, A.V., Ed.; Nature Conservation Agency: Sigulda, Latvia, 2017; pp. 128-174.

55. Wohl, E.E.; Angermeier, P.L.; Bledsoe, B.; Kondolf, G.M.; MacDonnell, L.; Merritt, D.M.; Palmer, M.A.; Poff, N.L.; Tarboton, D. River restoration. Water Resour. Res. 2005, 41, 1-12. [CrossRef]

56. Beechie, T.J.; Sear, D.A.; Olden, J.D.; Pess, G.R.; Buffington, J.M.; Moir, H.; Roni, P.; Pollock, M.M. Process-based principles for restoring river ecosystems. BioScience 2010, 60, 209-222. [CrossRef]

57. Bernhardt, E.S.; Palmer, M.A. River restoration-The fuzzy logic of repairing reaches to reverse watershed scale degradation. Ecol. Appl. 2011, 21, 1926-1931. [CrossRef]

58. Dufour, S.; Piégay, H. From the myth of a lost paradise to targeted river restoration: Forget natural references and focus on human benefits. River Res. Appli. 2009, 25, 568-581. [CrossRef] 
59. Kondolf, G.M.; Boulton, A.; O’Daniel, S.; Poole, G.; Rahel, F.; Stanley, E.; Wohl, E.; Bang, A.; Carlstrom, J.; Cristoni, C.; et al. Process-based ecological river restoration: Visualising three-dimensional connectivity and dynamic vectors to recover lost linkages. Ecol. Soc. 2006, 11, 1-17. [CrossRef]

60. McDonald, A.; Lane, S.N.; Haycock, N.E.; Chalk, E.A. Rivers of dreams: On the gulf between theoretical and practical aspects of an upland river restoration. Trans. Inst. Br. Geogr. 2004, 29, 257-281. [CrossRef]

61. Palmer, M.A.; Bernhardt, E.S.; Allan, J.D.; Lake, P.S.; Alexander, G.; Brooks, S.; Carr, J.; Clayton, S.; Dahm, C.; Follstad Shah, J.; et al. Standards for ecologically successful river restoration. J. Appl. Ecol. 2005, 42, $208-217$. [CrossRef]

62. Naiman, R.J. Socio-ecological complexity and the restoration of river ecosystems. Inland Waters 2013, 3, 391-410. [CrossRef]

63. Deffner, J.; Haase, P. The societal relevance of river restoration. Ecol. Soc. 2018, 23, 35. [CrossRef]

64. Wu, J. Landscape sustainability science: Ecosystem services and human well-being in changing landscapes. Landsc. Ecol. 2013, 28, 999-1023. [CrossRef]

65. Albuquerque, U.P.; Cruz, L.V.F.; Lucena, R.F.P.; Alves, R.R.N. (Eds.) Methods and Techniques in Ethnobiology and Ethnoecology; Springer: New York, NY, USA, 2014.

66. Martin, G.J. Ethnobotany. A Methods Manual; Chapman\&Hall: London, UK, 1995.

67. Biedroń, I.; Bogdańska-Warmuz, R.; Borzuchowska, J.; Brzóska, P.; Dondajewska, R.; Drożdżal, E.; Filipczyk, J.; Furdyna, A.; Gołdyn, R.; Grygoruk, M.; et al. National Programme of Restoration of Surface Waters of Poland; Materials of the National Board for Water Management (Krajowy Zarząd Gospodarki Wodnej): Warsaw, Poland, 2020.

68. Meals, D.W.; Dressing, S.A.; Davenport, T.E. Lag time in water quality response to best management practices: A review. J. Environ. Qual. 2010, 39, 85-96. [CrossRef]

69. Muhar, S.; Januschke, K.; Kail, J.; Poppe, M.; Schmutz, S.; Hering, D.; Buijse, A.D. Evaluating good-practice cases for river restoration across Europe: Context, methodological framework, selected results and recommendations. Hydrobiologia 2016, 769, 3-19. [CrossRef]

70. Szałkiewicz, E.; Jusik, S.; Grygoruk, M. Status of and Perspectives on River Restoration in Europe: 310000 EUR per Hectare of Restored River. Sustainability 2017, 10, 129.

71. Menzies, C.R.; Butler, C. Traditional Ecological Knowledge and Natural Resource Management; University of Nebraska Press: New York, NY, USA, 2006.

72. Gómez-Baggethun, E.; Reyes-García, V.; Olsson, P.; Montes, C. Traditional ecological knowledge and community resilience to environmental extremes: A case study in Doñana, SW Spain. Glob. Environ. Change 2012, 22, 640-650. [CrossRef]

73. McDonald, T.; Gann, G.D.; Jonson, J.; Dixon, K.W. International Standards for the Practice of Ecological Restoration-Including Principles and Key Concepts; Society for Ecological Restoration: Washington, DC, USA, 2016.

74. SER [Society for Ecological Restoration International Science \& PolicyWorking Group]. The SER International Primer on Ecological Restoration. \& Tucson: Society for Ecological Restoration International. 2004. Available online: www.ser.org (accessed on 14 December 2017).

75. Bączyk, A.; Wagner, M.; Okruszko, T.; Grygoruk, M. Influence of technical maintenance measures on ecological status of agricultural lowland rivers-Systematic review and implications for river management. Sc. Total Environ. 2018, 627, 189-199. [CrossRef]

76. Higgs, E. The Two-Culture Problem: Ecological Restoration and the Integration of Knowledge. Restor. Ecol. 2005, 13, 159-164. [CrossRef]

77. Wehi, R.M. Indigenous ancestral sayings contribute to modern conservation partnerships: Examples using Phormium tenax. Ecol. Appl. 2009, 19, 267-275. [CrossRef] [PubMed]

78. Morandi, B.; Piégay, H.; Lamoroux, N.; Vaudor, L. How is success or failure in river restoration projects evaluated? Feedback from French restoration projects. J. Environ. Manag. 2014, 137, 178-188. [CrossRef] [PubMed]

79. Wortley, L.; Hero, J.M.; Howes, M. Evaluating Ecological Restoration Success: A Review of the Literature. Restor. Ecol. 2013, 21, 537-543. [CrossRef]

80. Pander, J.; Geist, J. Ecological indicators for stream restoration success. Ecol. Indic. 2013, 30, 106-118. [CrossRef] 
81. Jähnig, S.C.; Lorenz, A.W.; Hering, D.; Antons, C.; Sundermann, A.; Jedicke, E.; Haase, P. River restoration success: A question of perception. Ecol. Appl. 2011, 21, 2007-2015. [CrossRef]

82. Hammond, D.; Mant, J.; Holloway, J.; Elbourne, N.; Janes, M. Practical River Restoration Appraisal Guidance for Monitoring Options (PRAGMO); The River Restoration Centre: Cranfield, UK, 2011; pp. 1-330.

83. Clusa, L.; Miralles, L.; Fernández, S.; García-Vázquez, E.; Dopico, E. Public knowledge of alien species: A case study on aquatic biodiversity in North Iberian rivers. J. Nat. Conserv. 2018, 42, 53-61. [CrossRef]

84. Ban, N.C.; Mills, M.; Tam, J.; Hicks, C.C.; Klain, S.; Stoeckl, N.; Chan, K.M. A social-ecological approach to conservation planning: Embedding social considerations. Front. Ecol. Environ. 2013, 11, 194-202. [CrossRef]

85. Webber, H. The Greening of the Hill: Revegetation around Broken Hill in the 1930s; Hyland House: Melbourne, Australia, 1992.

86. Cairns, J. The status of the theoretical and applied science of restoration ecology. Environ. Prof. 1991, 13, 186-194.

87. Pierotti, R.; Wildcat, D. Traditional ecological knowledge: The third alternative (commentary). Ecol. Appl. 2000, 10, 1333-1340. [CrossRef]

88. Yibarbuk, D.; Whitehead, P.J.; Russell-Smith, J.; Jackson, D.; Godjuwa, C.; Fisher, A.; Cooke, P.; Choquenot, D.; Bowman, D.M.J.S. Fire ecology and Aboriginal land management in central Arnhem Land, northern Australia: A tradition of ecosystem management. J. Biogeogr. 2001, 28, 325-343. [CrossRef]

89. Cuerrier, A.; Turner, N.J.; Gomes, T.C.; Garibaldi, A.; Downing, A. Cultural Keystone Places: Conservation and Restoration in Cultural Landscapes. J. Ethnobiol. 2015, 35, 427-448. [CrossRef]

90. Johannes, R.E. Traditional Ecological Knowledge: A Collection of Essays; IUCN: Cambridge, UK, 1989.

(C) 2020 by the authors. Licensee MDPI, Basel, Switzerland. This article is an open access article distributed under the terms and conditions of the Creative Commons Attribution (CC BY) license (http://creativecommons.org/licenses/by/4.0/). 